\title{
A Bioorthogonal Small Molecule Selective Polymeric "Clickase"
}

Junfeng Chen ${ }^{\dagger} \mathrm{Ke} \mathrm{Li}^{\dagger}{ }^{\dagger}$ Sarah E. Bonson ${ }^{\dagger}$ and Steven C. Zimmerman*,†,*

'Department of Chemistry, University of Illinois, Urbana, Illinois 61801, United States.

Center for Biophysics and Quantitative Biology, University of Illinois, Urbana, Illinois 61801, United States.

\section{Contents}

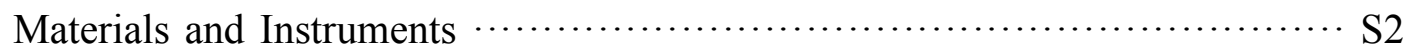

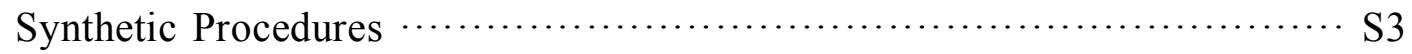

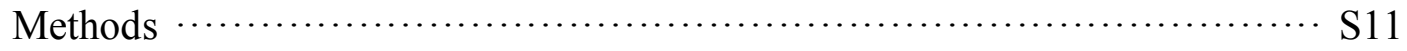

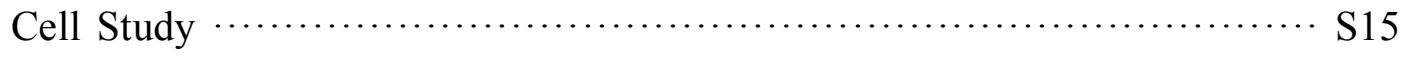

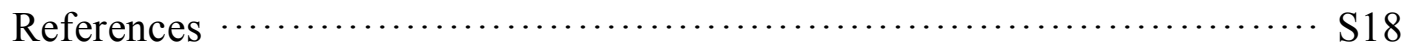




\section{Materials and Instruments:}

All reagents were purchased from Acros Organics, Fisher Scientific, Cambridge Chemical Technologies, Chem-Impex International, AK Scientific, TCI America, ProteinMods, AA block, or Sigma-Aldrich, and used without further purification unless otherwise noted. For the synthetic procedures, DCM, THF, acetonitrile, DMSO and DMF were stored over activated $4 \AA$ molecular sieves. NMR spectra were recorded using Varian U500, Bruker CB500 or VNS750NB spectrometers in the NMR Laboratory, School of Chemical Science, University of Illinois. Spectra were processed by using MestReNova (v8.1). The chemical shift $(\delta)$ is listed in ppm and the coupling constants $(J)$ are in Hz. Mass spectral analyses were provided by the Mass Spectrometry Laboratory, School of Chemical Science, University of Illinois, using ESI on a Waters Micromass Q-Tof spectrometer, FD on a Waters 70-VSE spectrometer. Transmission electron microscopy (TEM) was performed on a JEOL 2100 Cryo TEM, Materials Research Laboratory, University of Illinois at Urbana-Champaign. Fluorescence experiments were performed on a Horiba FluoroMax-4 fluorometer with FluorEssence (v3.5) software. Fluorescence polarization experiments were performed on an Analyst HT plate reader. Confocal microscopy studies were performed on a Leica SP8 UV/Visible Laser Confocal Microscope. The RAW data files were processed using OriginPro2019 and imported into Adobe Illustrator CC for coloring and annotation. 


\section{Synthetic Procedures}

\section{Synthesis of Di-Alkyne-PEG(3)}

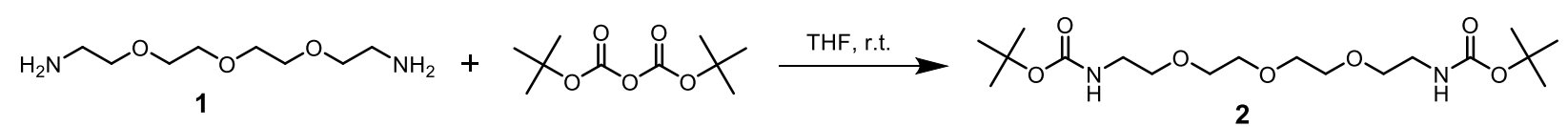

In a $20 \mathrm{~mL}$ glass vial, $500 \mathrm{mg}(2.6 \mathrm{mmol})$ of 1 was suspended in $5 \mathrm{~mL}$ of SPS dried THF, and $1.36 \mathrm{~g}$ $(6.2 \mathrm{mmol})$ of $(\mathrm{Boc})_{2} \mathrm{O}$ was added with stirring. The mixture was stirred at room temperature for $12 \mathrm{~h}$. To the mixture was added $1 \mathrm{~mL}$ of water, and the mixture was stirred for another $12 \mathrm{~h}$. Volatiles were removed by using a rotary evaporator, and the crude product was dried under high vacuum. The crude $\mathbf{2}$ was used in the next step without further purification.

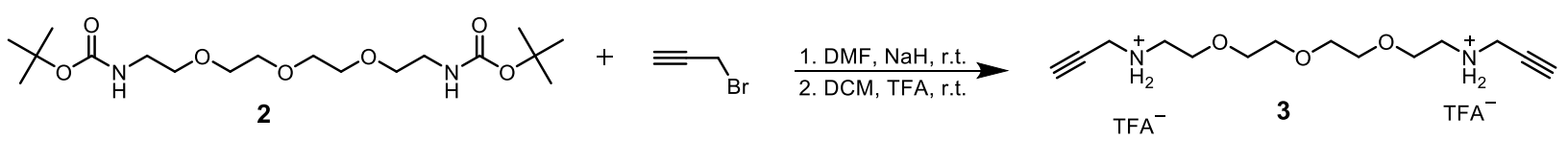

In a $300 \mathrm{~mL}$ round bottom flask, 2 from the last step was dissolved in $30 \mathrm{~mL}$ of SPS dried DMF and cooled in an ice bath. To the mixture was added $0.42 \mathrm{~g}(10.4 \mathrm{mmol})$ of $\mathrm{NaH}$ with fast stirring, and $1.55 \mathrm{~g}(10.4$ $\mathrm{mmol}$ ) of propargyl bromide ( $80 \mathrm{wt} \%$ in toluene) was added dropwise under $\mathrm{N}_{2}$. The mixture was allowed to warm up to room temperature over roughly $30 \mathrm{~min}$ and stirred for $12 \mathrm{~h}$. Volatiles were removed by using a rotary evaporator, and the mixture was suspended in $100 \mathrm{~mL}$ of saturated $\mathrm{NH}_{4} \mathrm{Cl}(\mathrm{aq})$. The mixture was extracted twice with $50 \mathrm{~mL}$ of ethyl acetate, and the combined organic layer was washed with $100 \mathrm{~mL}$ of water and $50 \mathrm{~mL}$ of brine. The organic layer was dried over $\mathrm{Na}_{2} \mathrm{SO}_{4}$, filtered and concentrated by using a rotary evaporator. The crude product was purified by using silica column chromatography with a gradient from DCM to $30 \%(\mathrm{v} / \mathrm{v})$ ethyl acetate in DCM to afford a brown gel-like solid. The resulting solid was redissolved in $3 \mathrm{~mL}$ of DCM and cooled in an ice bath. To the mixture was added $3 \mathrm{~mL}$ of TFA with stirring, and the mixture was allowed to warm up to room temperature over roughly $30 \mathrm{~min}$ and stirred for $6 \mathrm{~h}$. Volatiles were removed by using a rotary evaporator, and $50 \mathrm{ml}$ of toluene was added to the mixture and removed by using a rotary evaporator again. This process was repeated twice to afford $0.65 \mathrm{~g}(54 \%)$ of the title compound as a brown gel-like solid. ${ }^{1} \mathrm{H}$ NMR $\left(500 \mathrm{MHz}, \mathrm{CDCl}_{3}\right): \delta 9.22(\mathrm{~s}, 4 \mathrm{H}), 3.87(\mathrm{~d}, J=2.8,4 \mathrm{H})$, $3.75(\mathrm{t}, J=4.7,4 \mathrm{H}), 3.58(\mathrm{~m}, 8 \mathrm{H}), 3.30(\mathrm{t}, J=5.4,4 \mathrm{H}), 2.51(\mathrm{t}, J=2.8,4 \mathrm{H}) .{ }^{13} \mathrm{C} \mathrm{NMR}:\left(125 \mathrm{MHz}, \mathrm{CDCl}_{3}\right)$ : $\delta 77.9,72.7,70.3,70.1,65.5,46.0,36.7$. High resolution ESI-MS: $m / z$ calculated for $\mathrm{C}_{14} \mathrm{H}_{25} \mathrm{~N}_{2} \mathrm{O}_{3}\left([\mathrm{M}+\mathrm{H}]^{+}\right)$: 269.1865; found 269.1868. 
Synthesis of Dual-Protein-Binder (Al10)

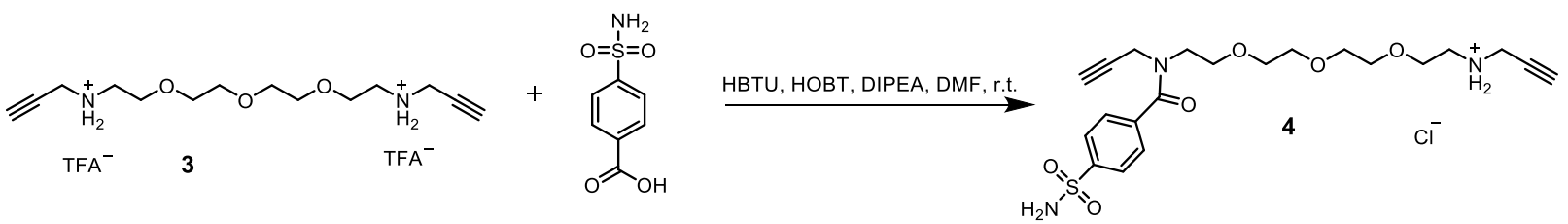

In a $20 \mathrm{ml}$ glass vial, $496 \mathrm{mg}(1.0 \mathrm{mmol})$ of 3 and $258 \mathrm{mg}(2.0 \mathrm{mmol})$ of DIPEA were dissolved in $1 \mathrm{~mL}$ of SPS dried DMF. In a separated vial, $417 \mathrm{mg}(1.1 \mathrm{mmol})$ of HBTU, $149 \mathrm{mg}(1.1 \mathrm{mmol})$ of HOBT, and 201 $\mathrm{mg}(1.0 \mathrm{mmol})$ of 4-sulfamolbenzoic acid were dissolved in $2 \mathrm{~mL}$ of SPS dried DMF, and the mixture was added to the 3 solution dropwise over $2 \mathrm{~h}$ at room temperature. The mixture was stirred at room temperature for additional $24 \mathrm{~h}$. Volatiles were removed by using a rotary evaporator, and most of the impurities were removed by using reverse phase C18 column chromatography with a gradient from $100 \%$ water to $100 \%$ $\mathrm{MeCN}$ containing $10 \mathrm{mM} \mathrm{HCl}$. The impure product 4 was used in the next step without further purification.

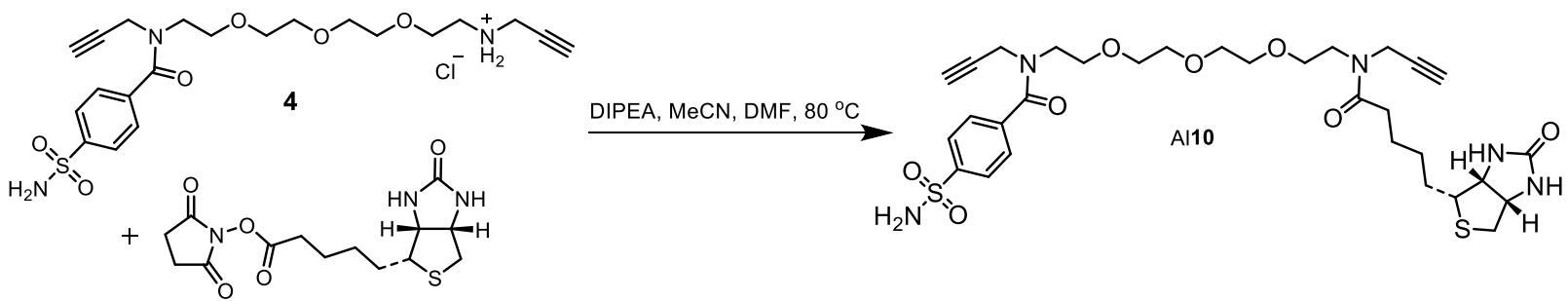

In a $20 \mathrm{~mL}$ glass vial, $230 \mathrm{mg}(0.4 \mathrm{mmol})$ of crude 4 from the last step and $63 \mathrm{mg}$ (490 mmol) of DIPEA were dissolved in a mixture of $1 \mathrm{~mL}$ of molecular sieve dried MeCN and $0.5 \mathrm{~mL}$ of SPS dried DMF. To the mixture was added biotin-NHS, and the mixture was stirred at $80^{\circ} \mathrm{C}$ for $3 \mathrm{~h}$. Volatiles were removed by using a rotary evaporator, and the mixture was purified by using a prep-HPLC with a gradient from $2 \%$ (v/v) $\mathrm{MeCN}$ in water to $100 \% \mathrm{MeCN}$ containing $0.1 \%$ (v/v) TFA to afford $152 \mathrm{mg}(22 \%)$ of the title compound as a white solid. High resolution ESI-MS: $m / z$ calculated for $\mathrm{C}_{31} \mathrm{H}_{44} \mathrm{~N}_{5} \mathrm{O}_{8} \mathrm{~S}_{2}\left([\mathrm{M}+\mathrm{H}]^{+}\right): 678.2631$; found 678.2640. The results from ${ }^{1} \mathrm{H}$ NMR, HPLC and ESI-MS are shown below.

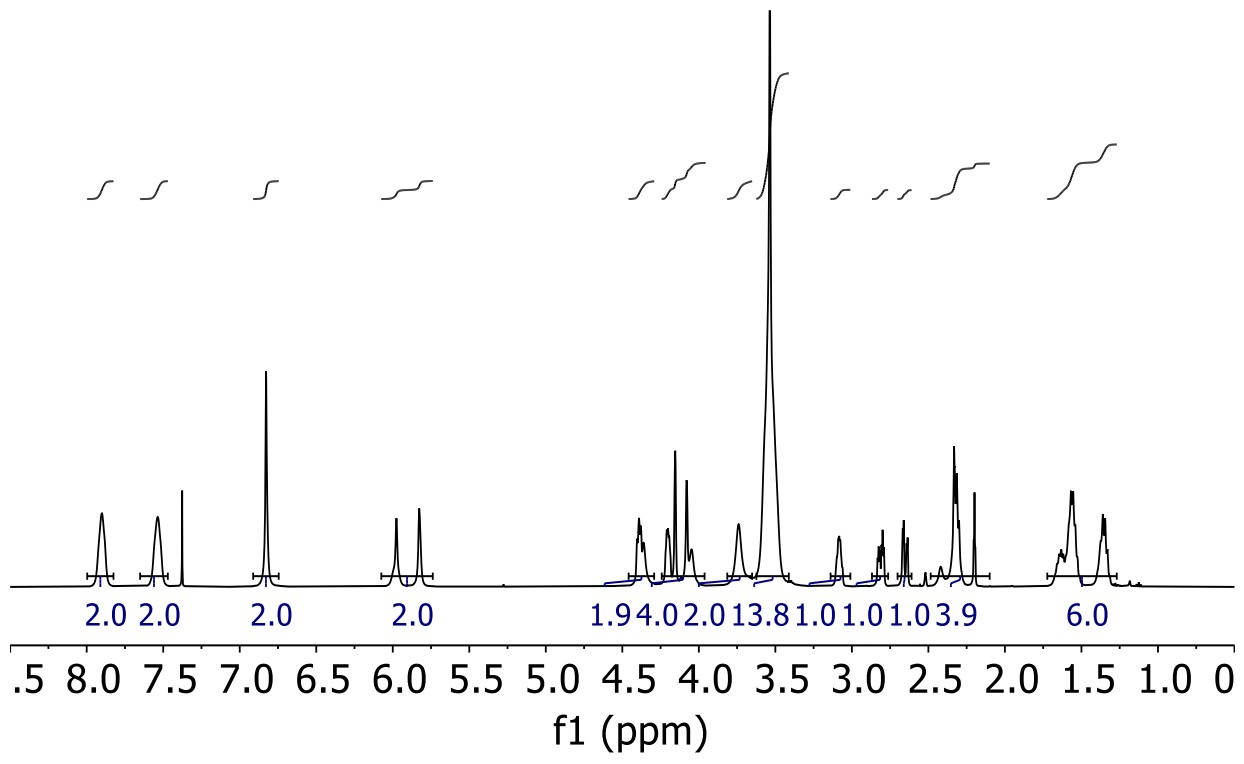




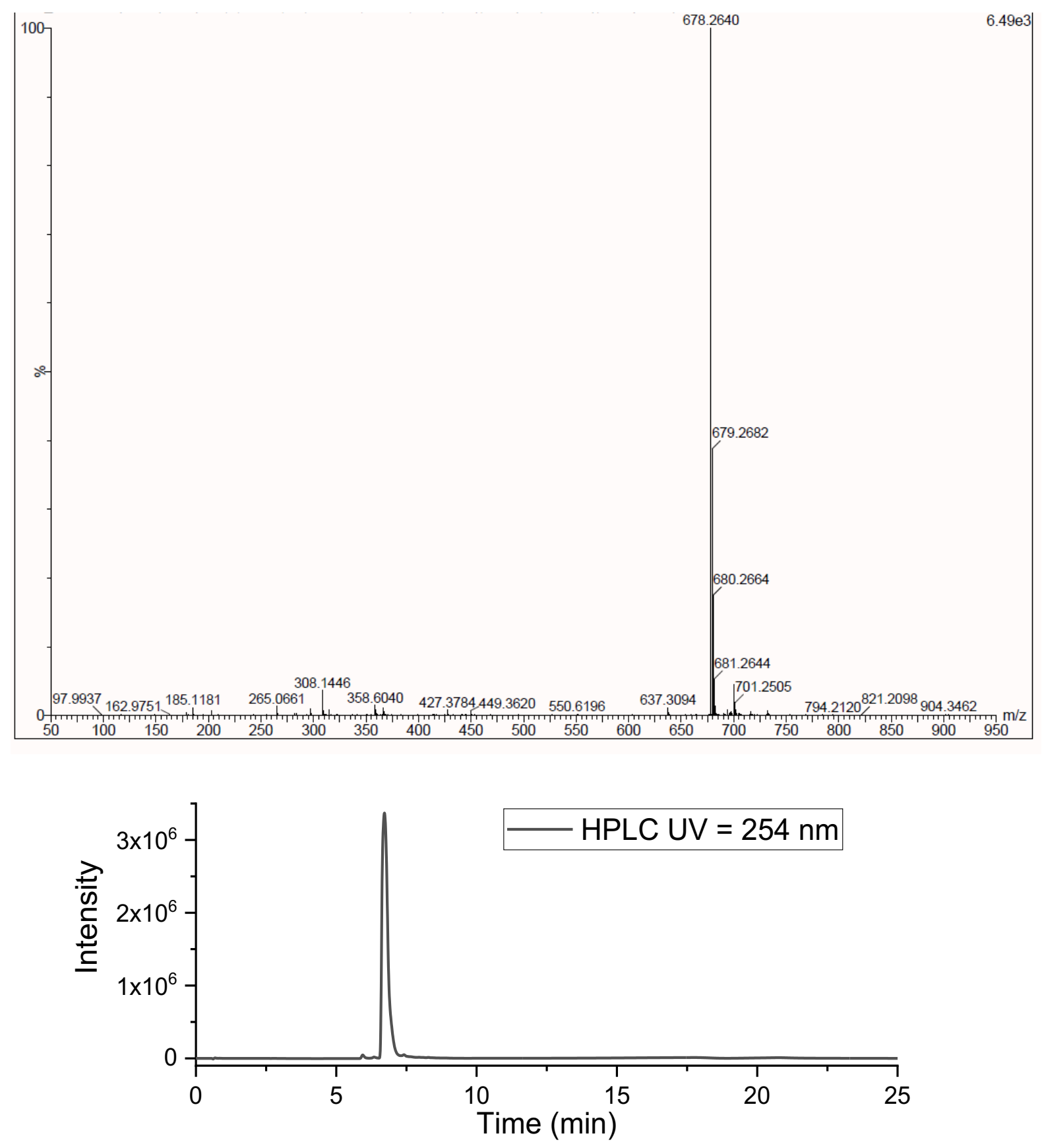




\section{Synthesis of Al7}

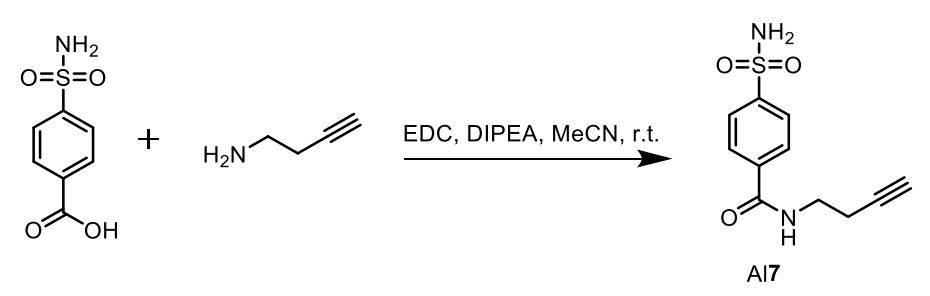

In a $200 \mathrm{~mL}$ round bottom flask, $1.0 \mathrm{~g}(5.0 \mathrm{mmol})$ of 4-sulfamolbenzoic acid, $1.4 \mathrm{~g}$ (7.5 mmol) of EDC$\mathrm{HCl}$ and $0.96 \mathrm{~g}(7.5 \mathrm{mmol})$ of DIPEA were suspended in $50 \mathrm{~mL}$ of $\mathrm{MeCN}$ and the mixture was stirred at room temperature for $24 \mathrm{~h}$. Volatiles were removed by using a rotary evaporator, and the crude product was purified by using silica column chromatography with a gradient from DCM to $5 \% \mathrm{v} / \mathrm{v} \mathrm{MeOH}$ in DCM to afford $1.02 \mathrm{~g}(81 \%)$ of the title compound as a white solid. ${ }^{1} \mathrm{H}$ NMR (500 MHz, DMSO-d6): $\delta 8.83(\mathrm{~s}, 1 \mathrm{H})$, $7.99(\mathrm{~d}, J=8.5,2 \mathrm{H}), 7.90(\mathrm{~d}, J=8.5,2 \mathrm{H}), 7.48(\mathrm{~s}, 2 \mathrm{H}), 3.41(\mathrm{q}, J=5.6,2 \mathrm{H}), 2.86(\mathrm{t}, J=3.0,1 \mathrm{H}), 2.46(\mathrm{~m}$, 2H). ${ }^{13} \mathrm{C}$ NMR: $\left(125 \mathrm{MHz}, \mathrm{CDCl}_{3}\right): \delta 164.9,146.8,138.2,128.3,125.7,83.4,72.7,38.9$, 20.9. High resolution ESI-MS: $m / z$ calculated for $\mathrm{C}_{11} \mathrm{H}_{13} \mathrm{~N}_{2} \mathrm{O}_{3} \mathrm{~S}\left([\mathrm{M}+\mathrm{H}]^{+}\right)$: 253.0647; found 253.0657.

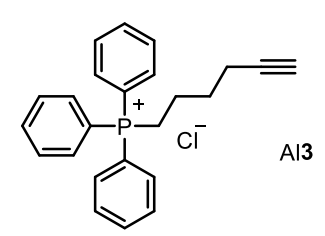

Compound Al3 was prepared using the reported procedure. ${ }^{1}$

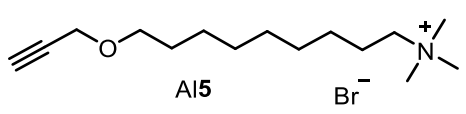

Compound A15 was prepared using the reported procedure. ${ }^{2}$

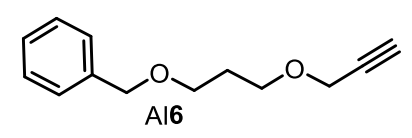

Compound Al6 was prepared using the reported procedure. ${ }^{3}$<smiles>COc1cc([N])cc(OC)c1</smiles><smiles>COc1cc(N)cc(OC)c1OC</smiles>

Compound $\mathrm{Az} 3$ and $\mathrm{Az} 4$ was prepared using the reported procedures. ${ }^{4}$ 


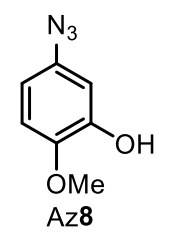

Compound Az8 was prepared using the reported procedure. ${ }^{5}$

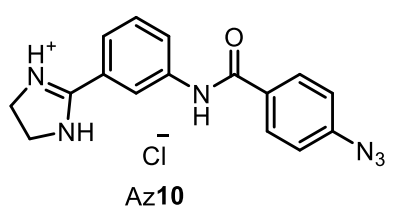

Compound Az10 was prepared using the reported procedure. ${ }^{6}$<smiles>COc1ccc2c(c1)CCCc1cc(OC)c(OC)c(OC)c1-2</smiles>

Compound Az11 was prepared as a $10 \mathrm{mM}$ solution in DMSO using the reported procedure. ${ }^{7}$ The result from HPLC is shown below.
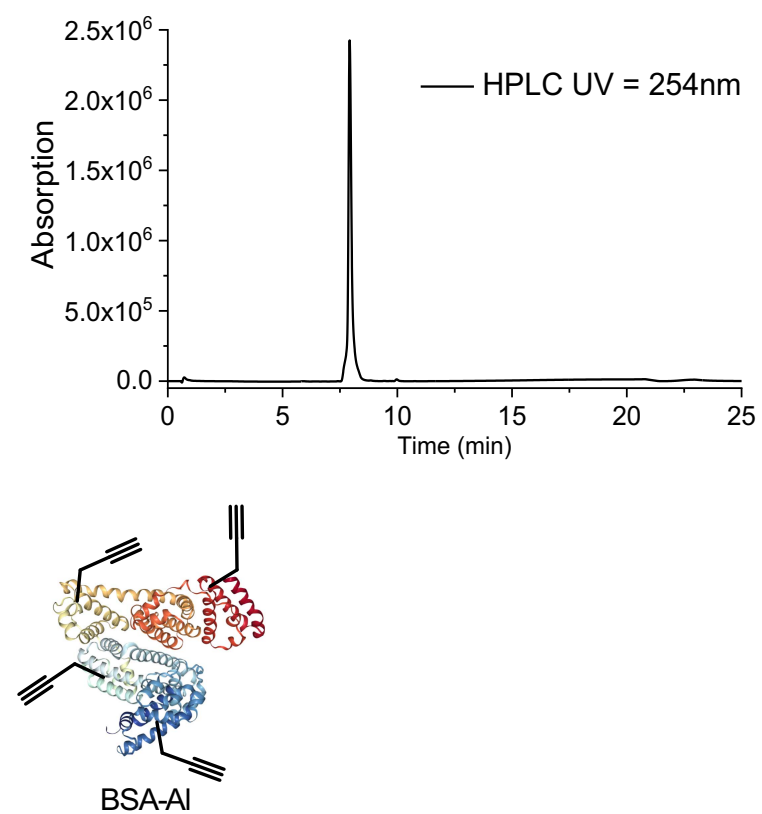

BSA-Al was prepared using the reported procedure. ${ }^{3}$ 


\section{Synthesis of Anticancer Compound Al3-Az3}

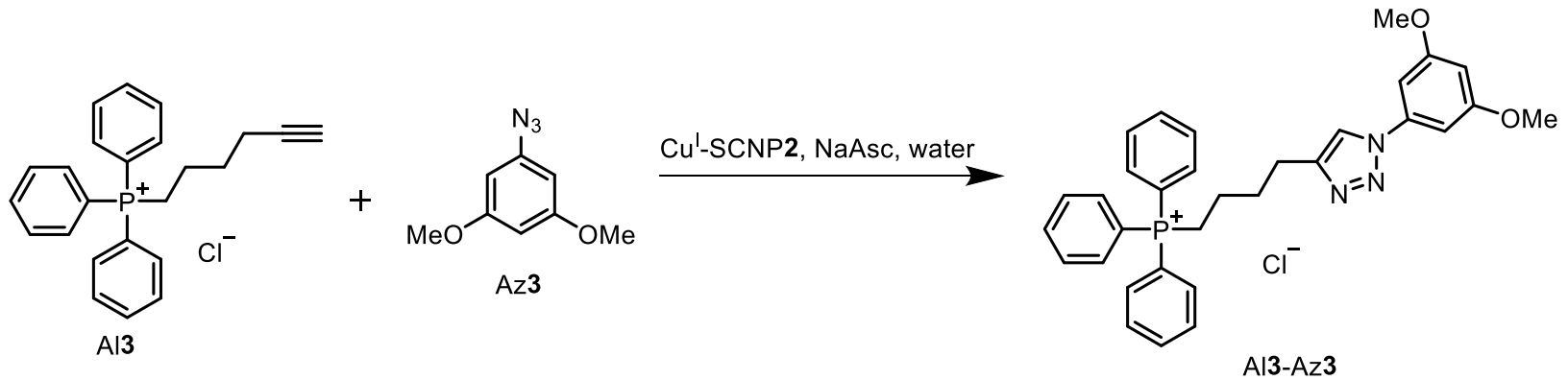

In a $20 \mathrm{~mL}$ glass vial, $102 \mathrm{mg}(0.27 \mathrm{mmol})$ of Al3 and $72 \mathrm{mg}(0.40 \mathrm{mmol})$ of Az3 were suspended in $2 \mathrm{ml}$ of water containing [Cu-SCNP1] $=100 \mu \mathrm{M}$ and $[\mathrm{NaAsc}]=20 \mathrm{mM}$. The mixture was stirred at $40^{\circ} \mathrm{C}$ for 2 $\mathrm{h}$. To the mixture was added $3 \mathrm{~mL}$ of DCM, and the organic layer was separated and purified by using silica column chromatography with a gradient from DCM to $10 \% \mathrm{MeOH}$ in DCM to afford $133 \mathrm{mg}(89 \%)$ of the title compound as a white solid. ${ }^{1} \mathrm{H}$ NMR $\left(500 \mathrm{MHz}, \mathrm{CDCl}_{3}\right): \delta 8.74(\mathrm{~s}, 1 \mathrm{H}), 7.76(\mathrm{~m}, 6 \mathrm{H}), 7.64(\mathrm{~m}, 3 \mathrm{H})$, $7.55(\mathrm{~m}, 6 \mathrm{H}), 7.06(\mathrm{~s}, 2 \mathrm{H}), 6.41(\mathrm{~s}, 1 \mathrm{H}), 3.85(\mathrm{~m}, 8 \mathrm{H}), 2.85(\mathrm{t}, \mathrm{J}=6.7,2 \mathrm{H}), 2.15(\mathrm{~m}, 2 \mathrm{H}), 1.61(\mathrm{~m}, 2 \mathrm{H}) .{ }^{13} \mathrm{C}$ NMR: $\left(125 \mathrm{MHz}, \mathrm{CDCl}_{3}\right): \delta 160.6,148.3,139.3,134.9,133.8,133.7,130.4,130.3,121.3,118.7,118.0$, 117.6, 101.7, 97.5, 56.1, 28.8, 28.6, 24.5, 22.5, 22.1, 21.4, 21.3. High resolution ESI-MS: $\mathrm{m} / \mathrm{z}$ calculated for $\mathrm{C}_{32} \mathrm{H}_{33} \mathrm{~N}_{3} \mathrm{O}_{2} \mathrm{P}\left([\mathrm{M}+\mathrm{H}]^{+}\right)$: 522.2310; found 522.2297.

\section{Synthesis of Amino functionalized PEG (6)}

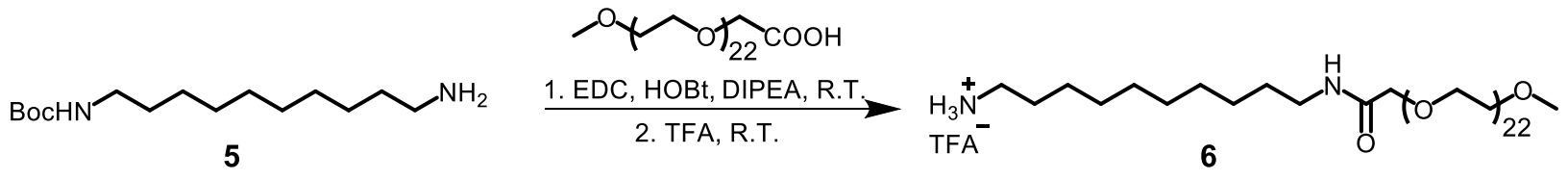

In a $20 \mathrm{~mL}$ vial, $2.0 \mathrm{~g}(2.0 \mathrm{mmol})$ of $\mathrm{MePEG}_{1000}-\mathrm{COOH}$ (the PEG compound has on average $1000 \mathrm{Da}$ molecular weight and 22 repeating units) was stirred with $575 \mathrm{mg}(3.0 \mathrm{mmol})$ of EDC-HCl, $1 \mathrm{~mL}(5.7$ mmol) of DIPEA and $270 \mathrm{mg}(2.0 \mathrm{mmol})$ of HOBt in $10 \mathrm{~mL}$ of DCM for $30 \mathrm{~min}$. To the mixture was added $544 \mathrm{mg}(2.0 \mathrm{mmol})$ of tert-butyl $\left(10\right.$-aminodecyl)carbamate $\left(\mathbf{5}\right.$, prepared using the reported procedure $\left.{ }^{3}\right)$ in $1 \mathrm{~mL}$ of $\mathrm{MeOH}$ and the mixture was stirred at room temperature for $16 \mathrm{~h}$. The mixture was washed with 20 $\mathrm{mL}$ of water twice, and the organic layer was dried over $\mathrm{Na}_{2} \mathrm{SO}_{4}$ and filtered. The solution was concentrated using a rotary evaporator and purified by column chromatography on silica (flash gel) with a solvent gradient from DCM to 10:90 (v/v) MeOH-DCM. The resulting viscous liquid was stirred in $10 \mathrm{~mL}$ of TFA at room temperature for $12 \mathrm{~h}$ to deprotect the $\mathrm{NH}_{2}$ group. The solution was concentrated using a rotary evaporator and precipitated in $40 \mathrm{~mL}$ of the $1: 1(\mathrm{v} / \mathrm{v})$ mixture of hexane and ether. The resulting gel-like solid was dried under high vacuum to afford $480 \mathrm{mg}(20 \%)$ of 8 as a waxy solid. ${ }^{1} \mathrm{H}$ NMR: $\delta 7.31(\mathrm{~m}, 4 \mathrm{H})$, $4.00(\mathrm{~s}, 2 \mathrm{H}), 3.65(\mathrm{~m}, 102 \mathrm{H}), 3.38(\mathrm{~s}, 3 \mathrm{H}), 3.27(\mathrm{~m}, 2 \mathrm{H}), 2.90(\mathrm{~m}, 2 \mathrm{H}), 1.62(\mathrm{~m}, 2 \mathrm{H}), 1.52(\mathrm{~m}, 2 \mathrm{H}), 1.30$ (m, 12H). 


\section{Polymer and Nanoparticle Synthesis}

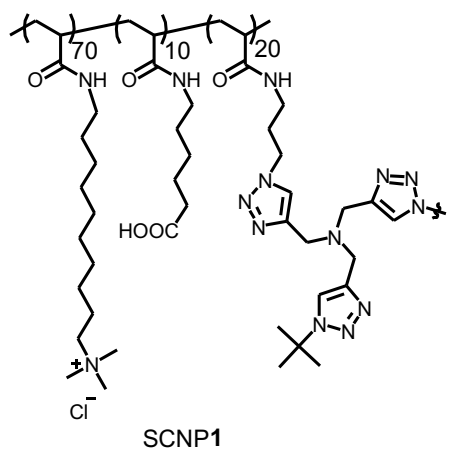

SCNP1 was prepared using the reported procedure. ${ }^{3}$

\section{Synthesis of SCNP2}

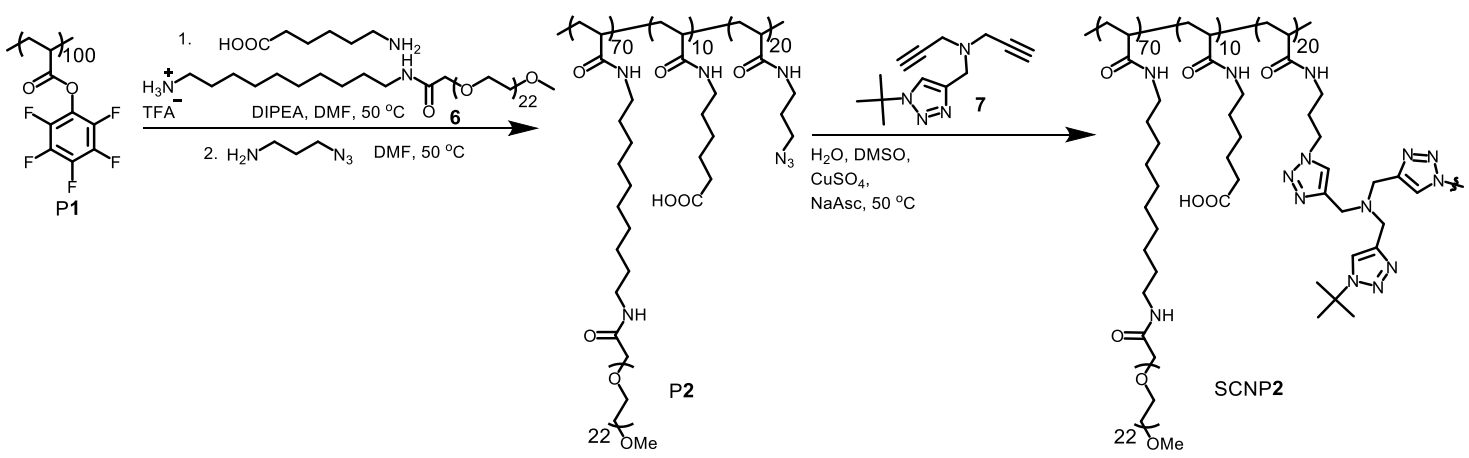

In a $20 \mathrm{~mL}$ screw-cap glass vial, $100 \mathrm{mg}(4.1 \mu \mathrm{mol})$ of P1, $347 \mathrm{mg}(289 \mu \mathrm{mol}, 0.7 \mathrm{eq})$ of 6 and $5.4 \mathrm{mg}$ (41 $\mu \mathrm{mol}, 0.1 \mathrm{eq}$ ) of 6-aminohexanoic acid were dissolved in a mixture of $1 \mathrm{~mL}$ of DMF and $100 \mu \mathrm{L}$ of DIPEA. The vial was capped, sealed with parafilm, and stirred at $50{ }^{\circ} \mathrm{C}$ for $3 \mathrm{~h}$. To the mixture, $17 \mathrm{mg}(165 \mu \mathrm{mol}$, 0.4 eq) of 3-azidopropan-1-amine was added and stirred at $50{ }^{\circ} \mathrm{C}$ for another $3 \mathrm{~h}$. The mixture was cooled to room temperature and precipitated in $14 \mathrm{~mL}$ of ethyl ether in a $15 \mathrm{~mL}$ centrifuge tube. $\mathrm{P} 2$ was collected by centrifugation and the supernatant was discarded. The gel-like solid was redissolved in $1 \mathrm{~mL}$ of $\mathrm{MeOH}$ in the centrifuge tube and $14 \mathrm{~mL}$ of ethyl ether was added to precipitate P2. The precipitate was collected by centrifugation, and supernatant was discarded. This process was repeated twice. The resulting gel-like polymer was dissolved in $3 \mathrm{~mL}$ of water and purified by dialysis ( $1 \mathrm{kD}$ cut-off) with water for $16 \mathrm{~h}$. The resulting solution was lyophilized to afford $\mathrm{P} 2$ as a gel-like solid.

In a $300 \mathrm{~mL}$ round bottom flask, $280 \mathrm{mg}(3.0 \mu \mathrm{mol})$ of P2 and $300 \mu \mathrm{L}$ of $100 \mathrm{mM}$ DMSO solution of 7 were dissolved in $60 \mathrm{~mL}$ of water. To the mixture, $60 \mu \mathrm{L}$ of $100 \mathrm{mM}$ aqueous solution of $\mathrm{CuSO}_{4}$ and 20 mg of sodium ascorbate were added under $\mathrm{N}_{2}$ atmosphere. The mixture was stirred at $30{ }^{\circ} \mathrm{C}$ for $2 \mathrm{~h}$, and the temperature was raised to $50{ }^{\circ} \mathrm{C}$ and stirred overnight. Volatiles were removed using a rotary evaporator and resulting SCNP2 was dissolved in $3 \mathrm{~mL}$ of water. The SCNP2 solution was added with $1 \mathrm{~g}$ of Chelex 100 chelating resin, and the mixture was gently shaken overnight to remove copper ions. The resin was removed by filtration. The SCNP2 solution was purified by dialysis (1 kD cut-off) with $1 \mathrm{M}$ aqueous solution of $\mathrm{NaCl}$ for $8 \mathrm{~h}$ and water for $48 \mathrm{~h}$. The resulting solution was lyophilized to afford $251 \mathrm{mg}(87 \%)$ 
of SCNP2 as a white powder. The conversion of each step is almost quantitative, and the yield is typically range from $80-90 \%$ due to losses during the purification.
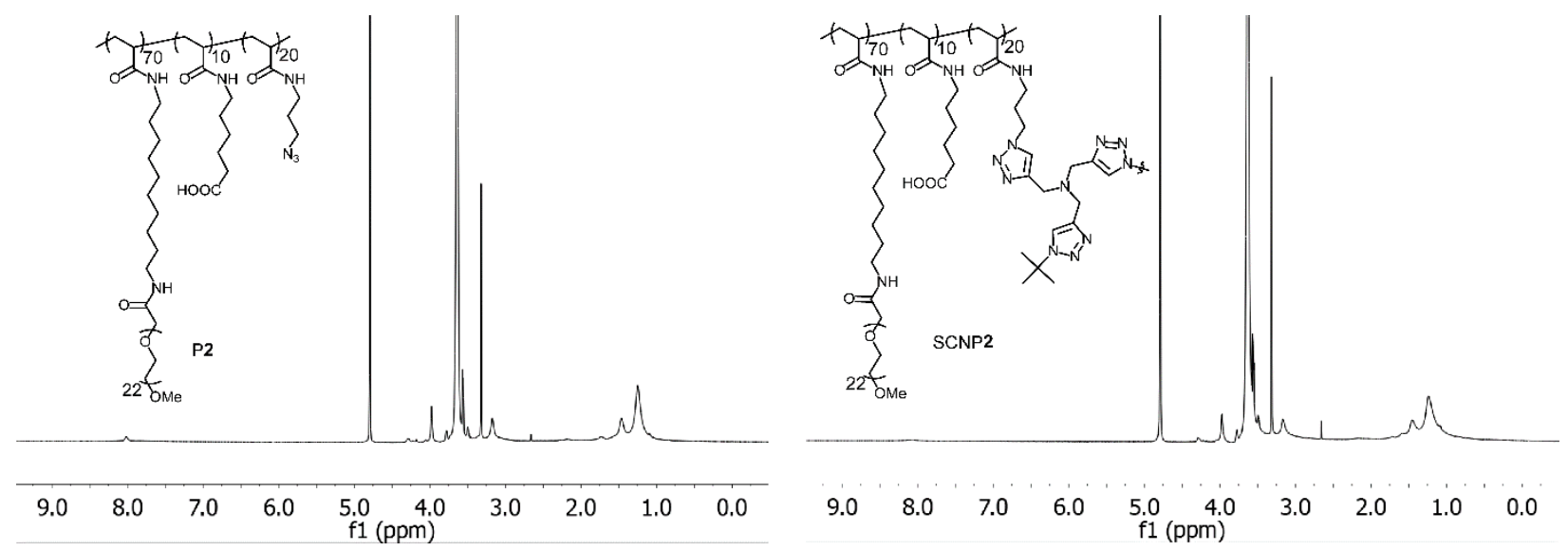

\section{Synthesis of SCNP2-Cy5}

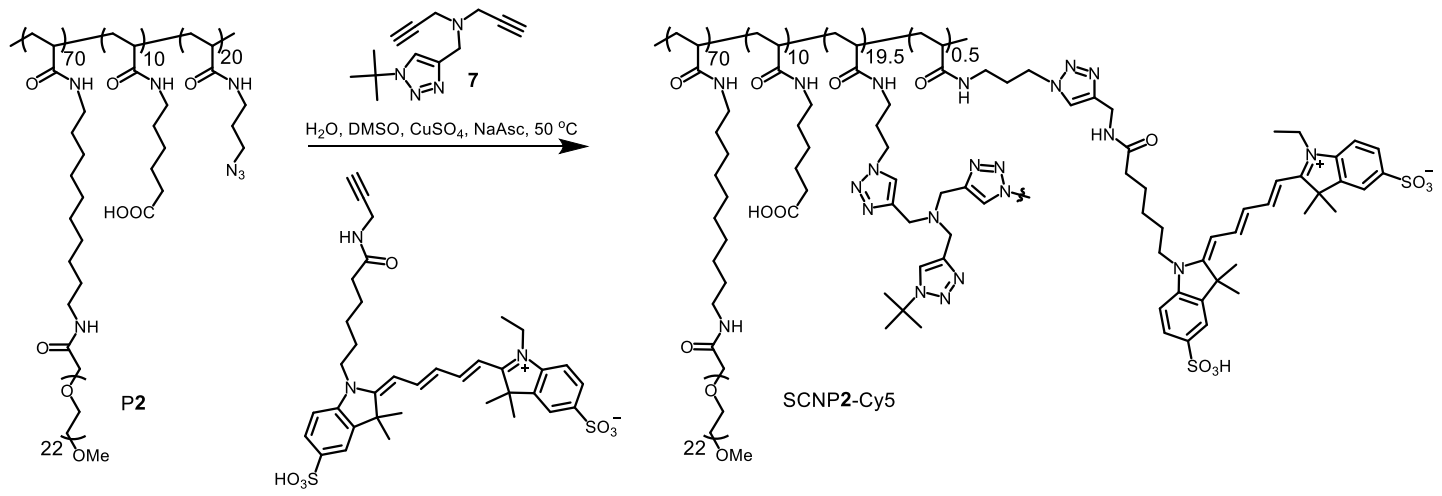

In a $20 \mathrm{~mL}$ screw-cap glass vial, $46 \mathrm{mg}(0.5 \mu \mathrm{mol})$ of P2 and $49 \mu \mathrm{L}$ of $100 \mathrm{mM}$ DMSO solution of 7 were dissolved in $10 \mathrm{~mL}$ of water and $25 \mu \mathrm{L}$ of $10 \mathrm{mM}$ DMSO solution of alkyne functionalized Cy 5 was added. To the mixture were added $10 \mu \mathrm{L}$ of $100 \mathrm{mM}$ aqueous solution of $\mathrm{CuSO}_{4}$ and $20 \mathrm{mg}$ of sodium ascorbate under $\mathrm{N}_{2}$ atmosphere. The mixture was stirred at $30^{\circ} \mathrm{C}$ for $2 \mathrm{~h}$, and the temperature was raised to $50{ }^{\circ} \mathrm{C}$ and stirred overnight. Volatiles were removed using a rotary evaporator and the resulting SCNP2-Cy5 was dissolved in $1 \mathrm{~mL}$ of water. The solution was added with $0.2 \mathrm{~g}$ of Chelex 100 chelating resin and the mixture was gently shaken overnight to remove copper ions. The resin was removed by filtration. The SCNP2-Cy5 solution was transferred to an Amicon tube with $10 \mathrm{kDa}$ cut-off and washed 6 times with water. 


\section{Methods}

\section{Transmission electron microscopy (TEM)}

To a UC-A on lacey gold TEM grid (Ted Pella) was added $8 \mu \mathrm{L}$ of $2 \mu \mathrm{M}$ solution of SCNP2 in fresh MilliQ water. The SCNP solution was carefully removed after 20 min by using a filter paper to absorb the solution. Ammonium molybdate $(2 \mathrm{wt} \%$ in water, $8 \mu \mathrm{L}$ ) was added to the grid surface to negatively stain the SCNP. The staining process was conducted for $20 \mathrm{~min}$ and the solution was removed using a filter paper. The TEM grid was allowed to air dry for $1 \mathrm{~h}$. The TEM imaging was performed on a JEOL 2100 Cryo TEM under $200 \mathrm{keV}$, and the images were processed using ImageJ.

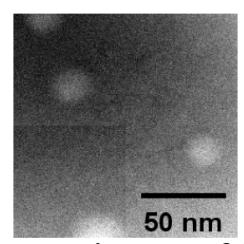

Figure S1. TEM image of SCNP2.

\section{Dynamic Light Scattering (DLS)}

The SCNP solution was prepared in fresh Milli-Q water to a concentration of $20 \mu \mathrm{M}$. To a disposable $4 \mathrm{~mL}$ plastic vial for the DLS instrument was added $1 \mathrm{~mL}$ of the solution and sonicated for around $30 \mathrm{~s}$ before the measurement. The light scattering and $\zeta$-potential were subsequently measured by using a Marvin Instrument Ltd. nanoZS Zetasizer.

Saturation Transfer Difference (STD) experiment. BSA and $\mathrm{Cu}^{\mathrm{II}}-\mathrm{SCNP2}$ were dissolved in deuterium oxide PBS buffer $(1 \mathrm{x}, \mathrm{pD}=7.4)$ to reach the concentration of $100 \mu \mathrm{M}$ for both protein and nanoparticle. STD spectra were collected with the water suppression STD method on a VNS750 spectrometer with the bio-pack software. During the saturation period, the aromatic region on BSA protein was irradiated at 7 ppm, and the irradiation time was ranged from $0.5 \mathrm{~s}$ to $5 \mathrm{~s}$. To minimize intramolecular signals from BSA, a $15 \mathrm{~ms}$ relaxation $\mathrm{T}_{2}$ filter was applied during the data acquisition. Spectra were processed by MestReNova (v8.1), and STD effect intensity was calculated for the trimethyl ammonium peak at $3.0 \mathrm{ppm}$ and alkyl chain peak at $1.2 \mathrm{ppm}$ through the equation: $\mathrm{STD}=\left(\mathrm{I}_{0}-\mathrm{I}_{\text {sat }}\right) / \mathrm{I}_{0}$.

Fluorescence Polarization. Fluorescein labelled BSA protein was dissolved in PBS buffer $(1 \mathrm{x}, \mathrm{pH}=7.4$, with/without additional $\mathrm{NaCl}$ ) at the concentration of $2 \mu \mathrm{M}$ with the concentration of $\mathrm{Cu}^{\mathrm{II}}$-SCNP2 ranging from 0 to $100 \mu \mathrm{M}$. The solutions were transferred to a black 384 -well plate, and $50 \mu \mathrm{L}$ of the solution was added to each well. The fluorescence polarization of solutions in each well was measured on an Analyst HT plate reader with the setup on fluorescein. The data was processed and fit using OriginPro2019.

Protein-Ligand Binding Simulation. The protein crystal structure was downloaded from protein data bank (PDB, https://www.rcsb.org/structure/2AVI). ${ }^{8}$ The data file was imported into Molecular Operating Environment (MOE). The chemical structure the biotin ligand was modified into Al8 or A19, and the energy was minimized by the MOE software. The structure of the complex was color for annotation. 
Fluorogenic Reactions. The fluorogenic CuAAC click reactions were performed in a $0.7 \mathrm{~mL}$ fluorimeter cuvette. $\mathrm{Cu}^{\mathrm{II}}$-SCNP was dissolved in $0.5 \mathrm{~mL}$ of PBS buffer $(1 \mathrm{x}, \mathrm{pH}=7.4)$ in the cuvette. DMSO stock solutions of substrates and aqueous stock solutions of NaAsc were added to give a final concentration of $[\mathrm{NaAsc}]=200 \mu \mathrm{M}$ and $2 \%(\mathrm{v} / \mathrm{v})$ of DMSO. The click reaction of 3-azido-7-hydroxy-coumarin (Az1) or 7-ethynylcoumarin (A111) restores its fluorescence. The intensity was monitored using a fluorimeter in kinetics mode, measuring the fluorescence intensity every $10 \mathrm{~s}$ at $\lambda_{\mathrm{em}}=480 \mathrm{~nm}$ with excitation at $\lambda_{\mathrm{ex}}=410$ $\mathrm{nm}$ for Az1 and $\lambda_{\mathrm{em}}=420 \mathrm{~nm}$ with excitation at $\lambda_{\mathrm{ex}}=328 \mathrm{~nm}$ for Al11. The initial rate was determined using the following procedure: $30 \mathrm{~s}$ after the start of the reaction, where the fluorescence signals start to increase linearly over time, the slope of this linear part (around 10 data points) was calculated in counts per second (CPS) increase per minute. For the reaction between Az1 and Al1, the slope was calculated into the initial reaction rate in " $\mu \mathrm{M} / \mathrm{min}$ " from the observed fluorescence intensity using the pure product as the standard. The initial reaction rates for the other alkyne substrates were calculated based on the assumption that the reactions reached $100 \%$ conversion, and the plateaued fluorescent signal was used as the fluorescence of the product. The fluorogenic CuAAC click reactions on BSA-Al were performed using a similar procedure with the initial rate presented directly as "CPS/min". The fluorogenic CuAAC click reactions on protein binder (Al1-10) were performed under the same procedure except the protein binder was premixed with the corresponding protein for $10 \mathrm{~min}$ before the start of the reaction.

For selective catalysis over BSA-Al and Al1. The fluorogenic CuAAC click reactions were performed in a $0.7 \mathrm{~mL}$ fluorimeter cuvette. In the total volume of $0.5 \mathrm{~mL}$ of PBS buffer $(1 \mathrm{x}, \mathrm{pH}=7.4)$ containing $\mathrm{Cu}^{\mathrm{II}}-$ SCNP1/ Cu ${ }^{\mathrm{II}}-\mathrm{SCNP2}(4 \mu \mathrm{M})$ and BSA-Al $(2 \mu \mathrm{M})$ in the cuvette, DMSO stock solutions of Az1 and Al1 were added to give a final concentration of $40 \mu \mathrm{M}$ and $2 \%(\mathrm{v} / \mathrm{v})$ of DMSO. NaAsc(aq) stock solution was added to give the final concentration of $200 \mu \mathrm{M}$. The click reactions were performed for $20 \mathrm{~min}$, and the solution was transferred to Amicon tubes with $10 \mathrm{kDa}$ cutoff. The reaction mixture was washed with PBS buffer containing 10\% DMSO for 6 times. The solutions passed through the tube were combined and the volume was normalized to $3 \mathrm{~mL}$. The volume of the solution stayed in the tube was normalized to $3 \mathrm{~mL}$. The solutions were measure by using a fluorimeter. $\lambda_{\mathrm{em}}=430-550 \mathrm{~nm}$ with excitation at $\lambda_{\mathrm{ex}}=410 \mathrm{~nm}$. The fluorescence intensity of the solution resided in the Amicon tube corresponded to the fluorogenic reaction on BSA-Al. The fluorescence intensity of the solution passed through the Amicon tube corresponded to the fluorogenic reaction on BSA-Al.

HPLC Yield Determination. The reaction was performed in a total volume of $2 \mathrm{~mL}$ of PBS buffer containing $[\mathrm{Az1}]=20 \mu \mathrm{M},[\mathrm{Al1}]=40 \mu \mathrm{M},\left[\mathrm{Cu}^{\mathrm{I}}-\mathrm{SCNP2}\right]=2 \mu \mathrm{M}$ and $[\mathrm{NaAsc}]=200 \mu \mathrm{M}$ at room temperature for $5 \mathrm{~min}$. The mixture was extracted three times with $500 \mu \mathrm{L}$ of DCM and separated by centrifugation. The organic layers were combined and evaporated under high vacuum. The resulting solid was redissolved in $400 \mu \mathrm{L}$ of $\mathrm{MeOH}$, and $100 \mu \mathrm{L}$ of the solution was injected to a HPLC analysis for analysis. The HPLC standard curve was prepared by injecting the HPLC with $100 \mu \mathrm{L}$ of 20, 100, $200 \mu \mathrm{M}$ of synthetically prepared Al1-Az1 and detected with UV $=254 \mathrm{~nm}$. The conversion was determined to be $105 \%$ by using the standard curve, which is within the error range (Figure S5). 
(a)

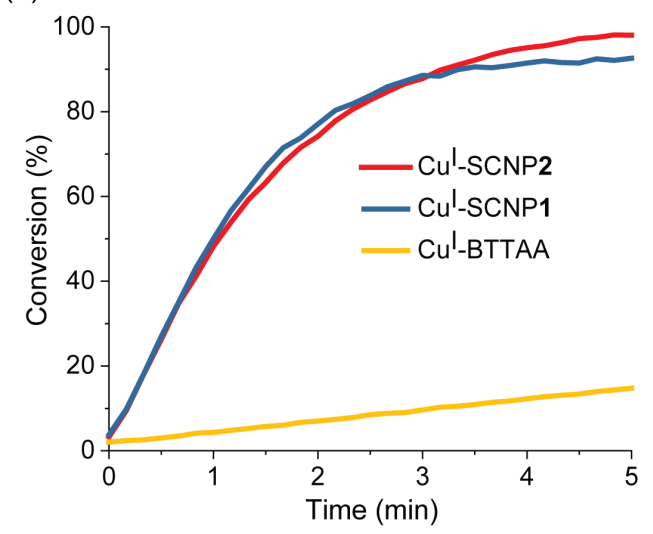

(b)

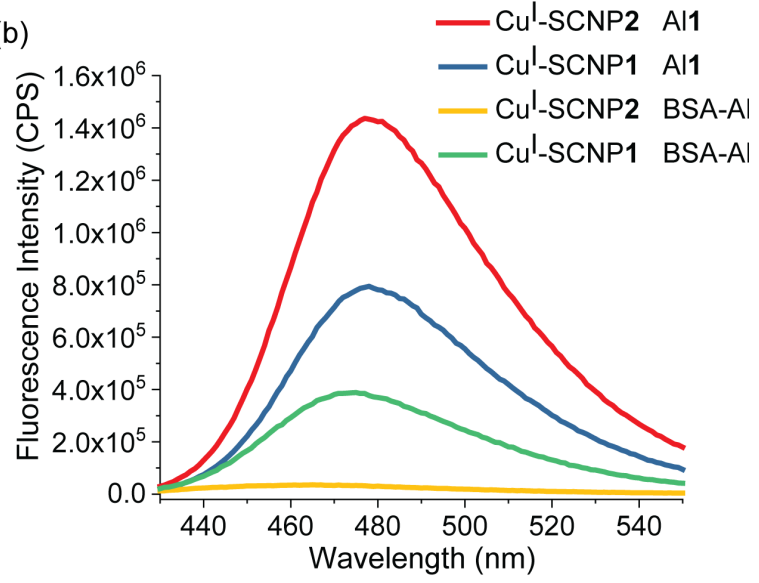

Figure S2. (a) Kinetics of reactions performed in PBS buffer containing [Az1] $=20 \mu \mathrm{M}$, [Al1] $=40 \mu \mathrm{M}$ and $[\mathrm{NaAsc}]=200 \mu \mathrm{M}$, by using $\left[\mathrm{Cu}^{\mathrm{I}}-\mathrm{SCNP} 1\right]=2 \mu \mathrm{M},\left[\mathrm{Cu}^{\mathrm{I}}-\mathrm{SCNP} 2\right]=2 \mu \mathrm{M}$ or $\left[\mathrm{Cu}^{\mathrm{I}}-\mathrm{BTTAA}\right]=20$ $\mu \mathrm{M}$ as the catalyst. (b) Fluorescence spectra of the separated reaction mixtures in PBS buffer containing: $\left[\mathrm{Cu}^{\mathrm{I}}-\mathrm{SCNP1} / 2\right]=4 \mu \mathrm{M},[\mathrm{Azl}]=[\mathrm{Al1}]=40 \mu \mathrm{M},[\mathrm{BSA}-\mathrm{Al}]=2 \mu \mathrm{M}$ and $[\mathrm{NaAsc}]=200 \mu \mathrm{M}$.

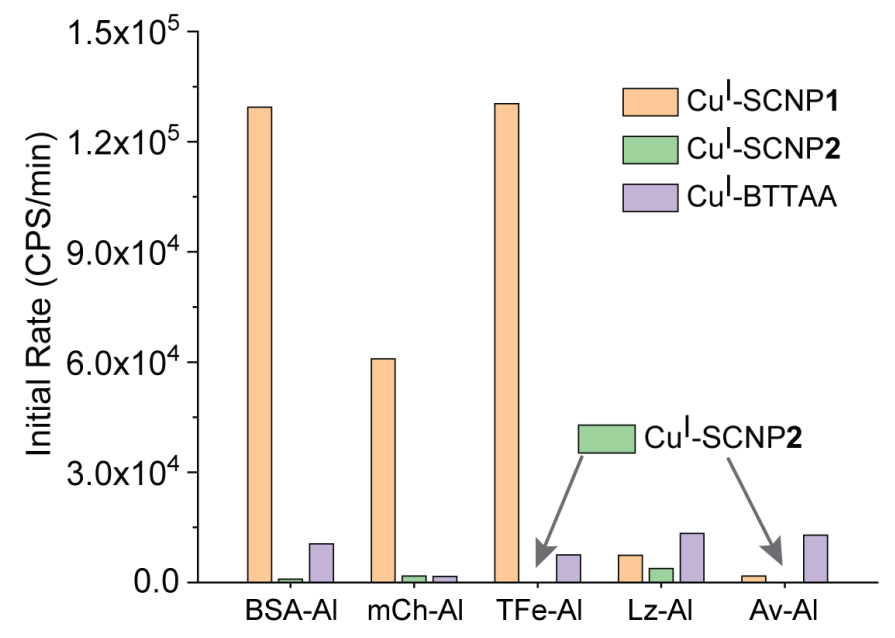

Figure S3. Initial reaction rates for small molecule and protein substrates with $\mathrm{Cu}^{\mathrm{II}}-\mathrm{SCNP} 1(2 \mu \mathrm{M})$ or $\mathrm{Cu}^{\mathrm{II}}-\mathrm{SCNP2}(2 \mu \mathrm{M})$ in PBS buffer $(1 \mathrm{x}, \mathrm{pH}=7.4)$ at room temperature. For protein substrate: protein $(2 \mu \mathrm{M}$, $5 \mu \mathrm{M}$ for Lz-Al) and Az1 (40 $\mu \mathrm{M})$. Data for SCNP1 and BTTAA from ref. 3. 

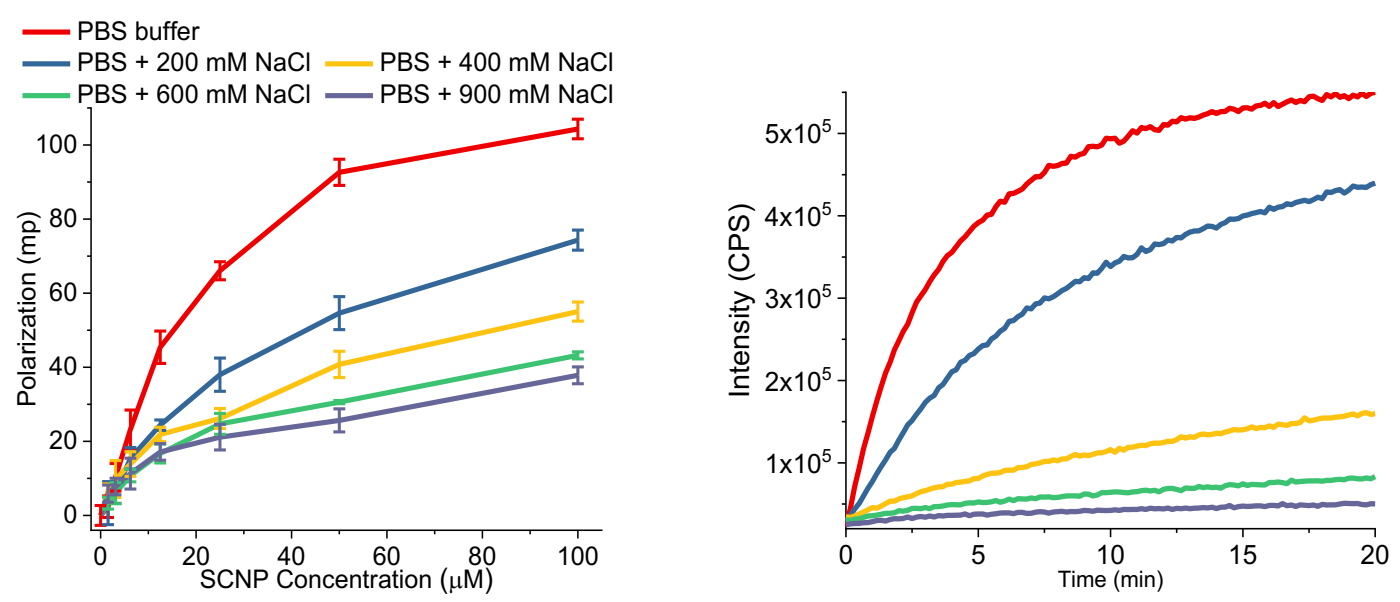

Figure S4. Fluorescence polarization of fluorescein labelled BSA $(2 \mu \mathrm{M})$ with different concentration of $\mathrm{Cu}^{\mathrm{II}}-\mathrm{SCNP} 1$ in PBS buffer $(1 \mathrm{x}, \mathrm{pH}=7.4)$ with different amount of extra $\mathrm{NaCl}$, and kinetics of reactions performed in PBS buffer containing [Az1 $]=40 \mu \mathrm{M},[\mathrm{BSA}-\mathrm{Al}]=2 \mu \mathrm{M}$ and $[\mathrm{NaAsc}]=200$ $\mu \mathrm{M}$, by using $\left[\mathrm{Cu}^{\mathrm{I}}-\mathrm{SCNP1}\right]=2 \mu \mathrm{M}$ as the catalyst in PBS buffer $(1 \mathrm{x}, \mathrm{pH}=7.4)$ with different amount of extra $\mathrm{NaCl}$,
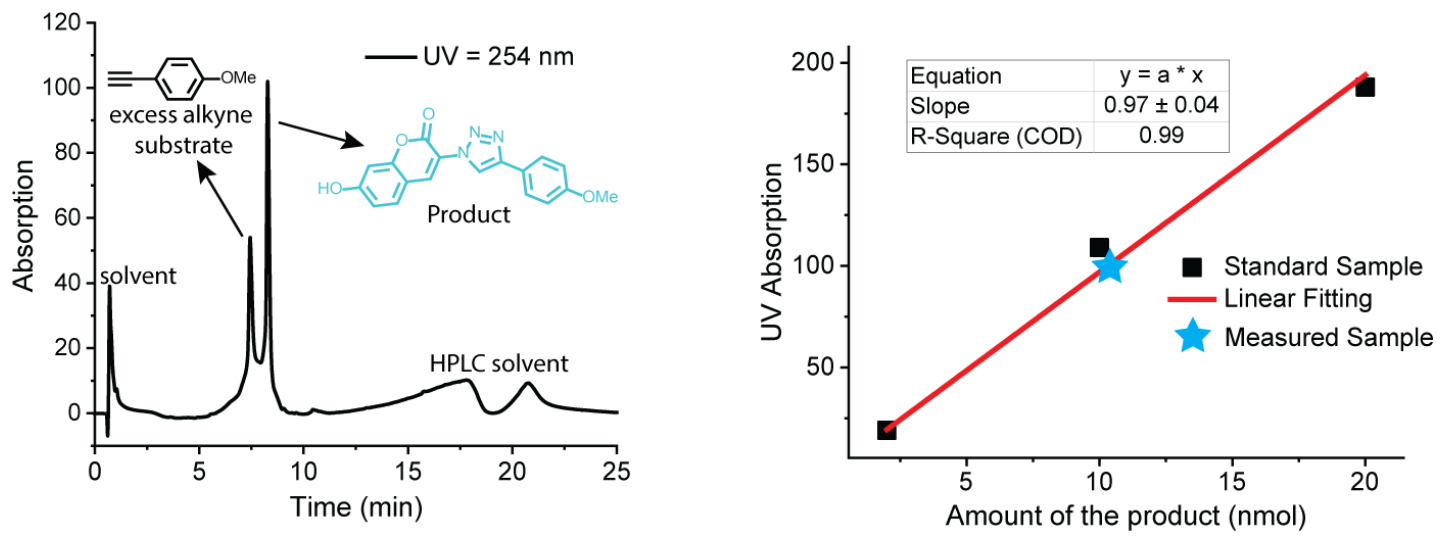

Figure S5. HPLC trace and the standard curve for the reaction conversion determination. 


\section{$\underline{\text { Cell Study }}$}

Cell Uptake of SCNPs. In Ibidi u-Dish $35 \mathrm{~mm}$ high dishes, $360000 \mathrm{HeLa}$ cells in $3 \mathrm{~mL}$ of DMEM media (10\% FBS added) containing $\mathrm{Cu}^{\mathrm{II}}-\mathrm{SCNP} 1-\mathrm{Cy} 5$ or $\mathrm{Cu}^{\mathrm{II}}-\mathrm{SCNP2}-\mathrm{Cy} 5$ was added to each dish, and the cells were incubated at $37{ }^{\circ} \mathrm{C}$ with $5 \% \mathrm{CO}_{2}$ for $24 \mathrm{~h}$. The cell media were removed, and each well was washed three times with $3 \mathrm{~mL}$ of PBS buffer. The images were taken by using confocal microscopy. Ex: $633 \mathrm{~nm}$, em: $650-700 \mathrm{~nm}$. (Figure S6)

Cell Uptake of $\mathrm{Cu}^{\mathrm{I}}$-SCNP2 Synthesized Compound. In Ibidi u-Dish $35 \mathrm{~mm}$ high dishes, $360000 \mathrm{HeLa}$ cells in $3 \mathrm{~mL}$ of DMEM media (10\% FBS added) was added to each dish, and the cells were incubated at $37{ }^{\circ} \mathrm{C}$ with $5 \% \mathrm{CO}_{2}$ for $24 \mathrm{~h}$. The cell media were removed, and each well was washed three times with 3 $\mathrm{mL}$ of PBS buffer. To each well was added $2 \mathrm{~mL}$ of PBS buffer containing [Cu $\left.{ }^{\mathrm{II}}-\mathrm{SCNP2}\right]=1 \mu \mathrm{M}$, [Az1] $=$ $20 \mu \mathrm{M}$ and $[\mathrm{Al1}]=20 \mu \mathrm{M}$. The cell image was focused and $20 \mu \mathrm{L}$ of PBS buffer containing [NaAsc] $=20$ $\mathrm{mM}$ was added. The images were taken by using confocal microscopy every $30 \mathrm{~s}$. ex $405 \mathrm{~nm}$, em 430-480 $\mathrm{nm}$. The intensity reached to maximum after around $10 \mathrm{~min}$.

Cytotoxicity of $\mathbf{C u}$-SCNP2. In a 96 wells plate, $10000 \mathrm{HeLa}$ cells were added to each well with $100 \mu \mathrm{L}$ of DMEM media (10\% FBS), and the cells were incubated at $37{ }^{\circ} \mathrm{C}$ with $5 \% \mathrm{CO}_{2}$ for $24 \mathrm{~h}$. The cell media were removed, and each well was washed 2 times with $100 \mu \mathrm{L}$ of PBS buffer. To each well was added 50 $\mu \mathrm{L}$ of PBS buffer containing $1,2,4,8$ or $16 \mu \mathrm{M}$ of $\mathrm{Cu}^{\mathrm{II}}$-SCNP2 and $100 \mu \mathrm{M}$ of NaAsc, and the cells were incubated at $37^{\circ} \mathrm{C}$ for $30 \mathrm{~min}$. To each well was added $50 \mu \mathrm{L}$ of DMEM media $(10 \% \mathrm{FBS})$, and the cells were incubated for $24 \mathrm{~h}$. The cell viability was measured by using MTT assay (Figure S8).

96 Wells Plate Drug Screening. In a 96 wells plate, $10000 \mathrm{HeLa}$ cells were added to each well with 100 $\mu \mathrm{L}$ of DMEM media (10\% FBS), and the cells were incubated at $37^{\circ} \mathrm{C}$ with $5 \% \mathrm{CO}_{2}$ for $24 \mathrm{~h}$. The cell media were removed, and each well was washed 2 times with $100 \mu \mathrm{L}$ of PBS buffer. To each well was added $50 \mu \mathrm{L}$ of PBS buffer containing $2 \%$ (v/v) DMSO, $1 \mu \mathrm{M}$ of $\mathrm{Cu}^{\mathrm{II}}-\mathrm{SCNP2}, 40 \mu \mathrm{M}$ of alkyne and azide substrates and $100 \mu \mathrm{M}$ of NaAsc, and the cells were incubated at $37^{\circ} \mathrm{C}$ for $30 \mathrm{~min}$. To each well was added $50 \mu \mathrm{L}$ of DMEM media (10\% FBS), and the cells were incubated for $24 \mathrm{~h}$. The cell viability was measured by using MTT assay. The experiments were performed twice and the average cell viability was presented in Figure 7. The control experiment was conducted under the same condition but without adding NaAsc (Figure S9).

Cytotoxicity of Al3-Az3. In a 96 wells plate, $10000 \mathrm{HeLa}$ cells were added to each well with $100 \mu \mathrm{L}$ of DMEM media (10\% FBS), and the cells were incubated at $37^{\circ} \mathrm{C}$ with $5 \% \mathrm{CO}_{2}$ for $24 \mathrm{~h}$. The cell media were removed, and each well was added DMEM media (10\% FBS) containing Al3-Az3 from $320 \mu \mathrm{M}$ with $2 \mathrm{x}$ dilution and $0.5 \% \mathrm{v} / \mathrm{v}$ DMSO. The cells were incubated at $37{ }^{\circ} \mathrm{C}$ for $24 \mathrm{~h}$. The cell viability was measured by using MTT assay (Figure S10). 


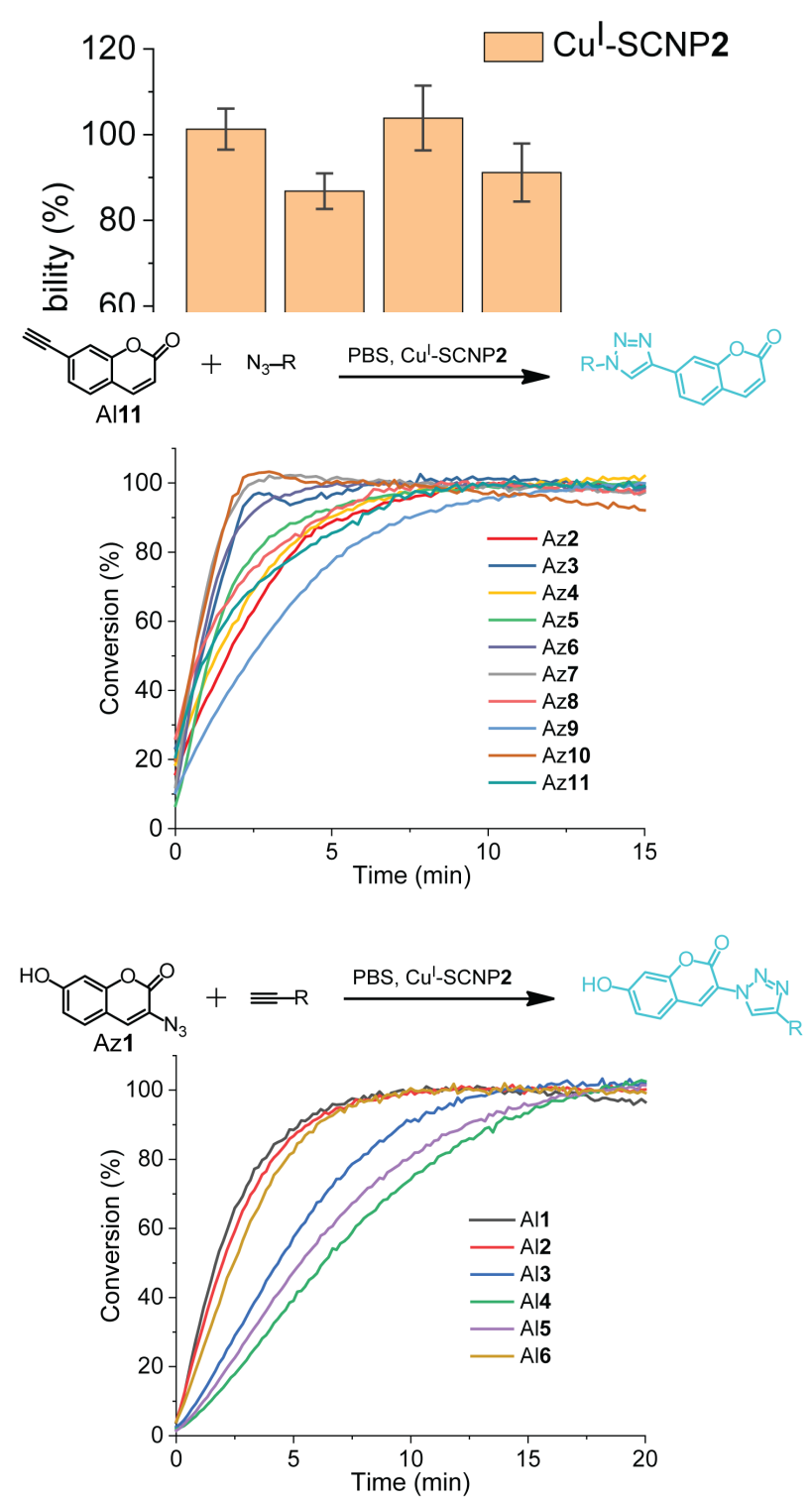

Figure S8. Fluorogenic reactions conducted with alkyne and azide substrates for drug screening. The reactions were performed in PBS buffer containing: $\left[\mathrm{Cu}^{\mathrm{I}}-\mathrm{SCNP} 2\right]=1 \mu \mathrm{M},[\mathrm{Az}]=[\mathrm{Al}]=40 \mu \mathrm{M}$ and $[\mathrm{NaAsc}]=100 \mu \mathrm{M}$.

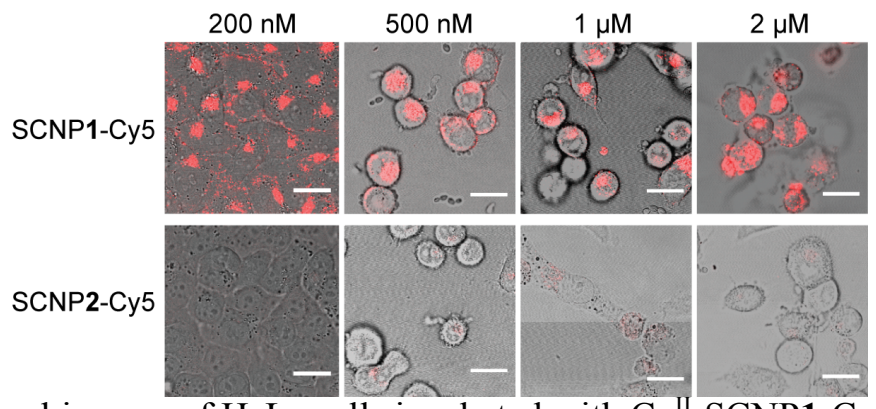

Figure S6. The confocal images of HeLa cells incubated with $\mathrm{Cu}^{\mathrm{II}}-\mathrm{SCNP} 1-\mathrm{Cy} 5$ or $\mathrm{Cu}^{\mathrm{II}}-\mathrm{SCNP} 2-\mathrm{Cy} 5$ for $24 \mathrm{~h}$ in DMEM media (10\% FBS added). 


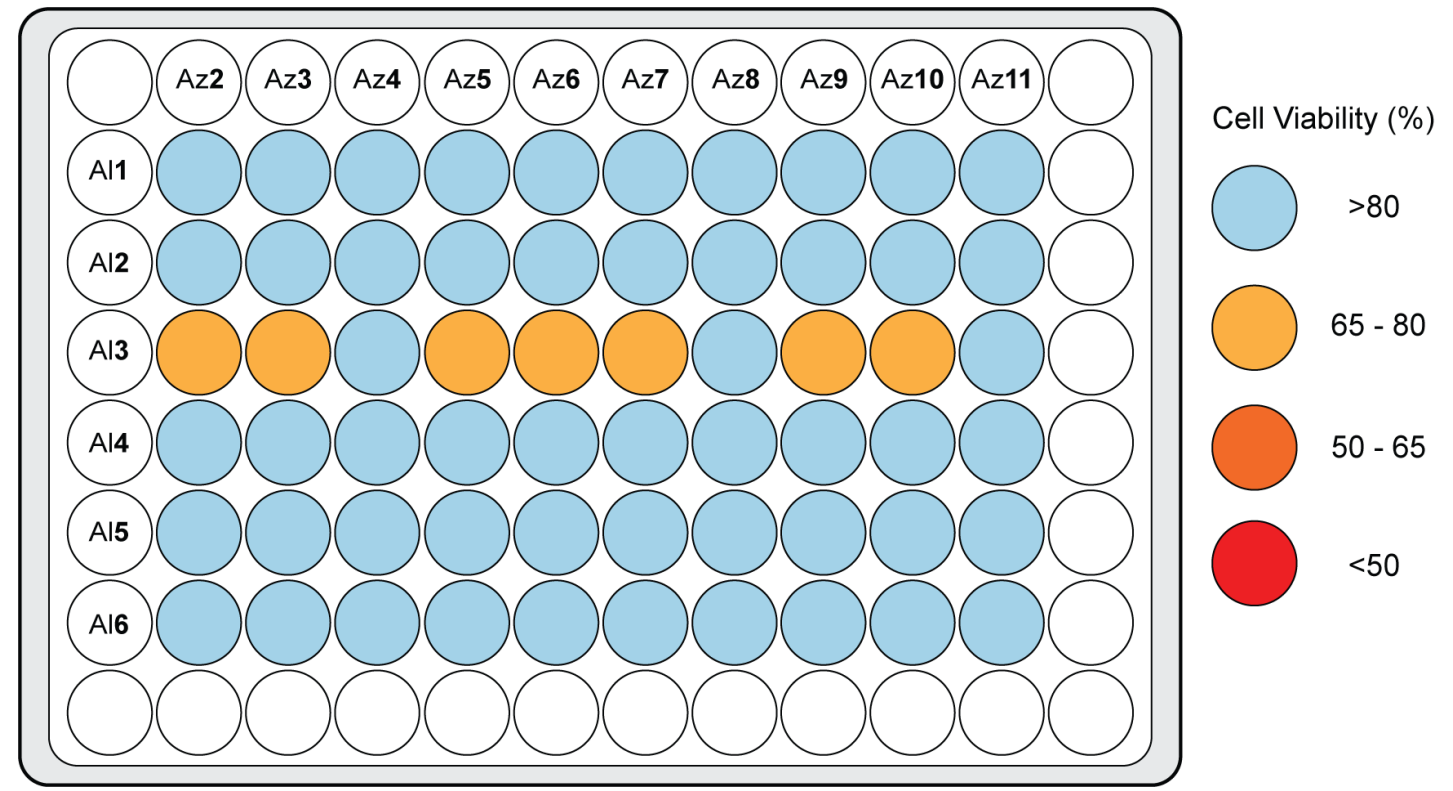

Figure S9. Control experiment performed for the 96 wells plate drug screening. The reactions were performed in PBS buffer containing: $\left[\mathrm{Cu}^{\mathrm{I}}-\mathrm{SCNP2}\right]=1 \mu \mathrm{M},[\mathrm{Az}]=[\mathrm{Al}]=40 \mu \mathrm{M}$ without NaAsc outside HeLa cells.
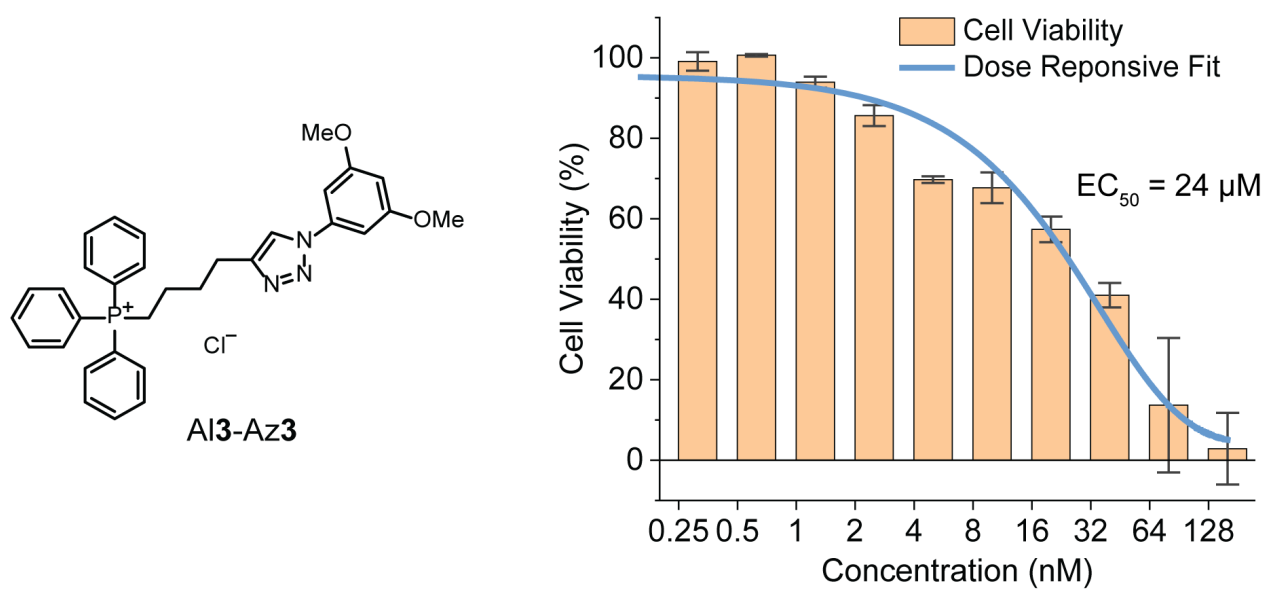

Figure S10. Cell viabilities of HeLa cells treated with different concentration of A13-Az3 in DMEM media (10\% FBS). 


\section{$\underline{\text { Reference }}$}

1. Luo, J.; Theron, R.; Sewell, L. J.; Hooper, T. N.; Weller, A. S.; Oliver, A. G.; Mclndoe, J. S. RhodiumCatalyzed Selective Partial Hydrogenation of Alkynes. Organometallics 2015, 34, 3021-3028.

2. Chen, J.; Wang, J.; Bai, Y.; Li, K.; Garcia, E. S.; Ferguson, A. L.; Zimmerman, S. C. Enzyme-like Click Catalysis by a Copper-Containing Single-Chain Nanoparticle. J. Am. Chem. Soc. 2018, 140, 1369513702.

3. Chen, J.; Wang, J.; Li, K.; Wang, Y.; Gruebele, M.; Ferguson, A. L.; Zimmerman, S. C. Polymeric "Clickase" Accelerates the Copper Click Reaction of Small Molecules, Proteins, and Cells. J. Am. Chem. Soc. 2019, 141, 9693-9700.

4. Necardo, C.; Alfano, A. I.; Del Grosso, E.; Pelliccia, S.; Galli, U.; Novellino, E.; Meneghetti, F.; Giustiniano, M.; Tron, G. C. Aryl Azides as Forgotten Electrophiles in the Van Leusen Reaction: A Multicomponent Transformation Affording 4-Tosyl-1-arylimidazoles. J. Org. Chem. 2019, 84, 1629916307.

5. Pagliai, F.; Pirali, T.; Del Grosso, E.; Di Brisco, R.; Tron, G. C.; Sorba, G.; Genazzani, A. A. Rapid Synthesis of Triazole-Modified Resveratrol Analogues via Click Chemistry. J. Med. Chem. 2006, 49, 467-470.

6. Bai, Y.; Feng, X.; Xing, H.; Xu, Y.; Kim, B. K.; Baig, N.; Zhou, T.; Gewirth, A. A.; Lu, Y.; Oldfield, E.; Zimmerman, S. C. A Highly Efficient Single-Chain Metal-Organic Nanoparticle Catalyst for AlkyneAzide "Click" Reactions in Water and in Cells. J. Am. Chem. Soc. 2016, 138, 11077-11080.

7. Meng, G.; Guo, T.; Ma, T.; Zhang, J.; Shen, Y.; Sharpless, K. B.; Dong, J. Modular click chemistry libraries for functional screens using a diazotizing reagent. Nature 2019, 574, 86-89.

8. Livnah, O.; Bayer, E. A.; Wilchek, M.; Sussman, J. L. Three-dimensional structures of avidin and the avidin-biotin complex. Proc. Natl. Acad. Sci 1993, 90, 5076-5080. 